Thin Film Diamond 


\section{Thin Film Diamond}

\section{Edited by A. Lettington and J.W. Steeds}

(2.) The Royal Society

9 SPRINGer-SCIENCE+BUSINESS MEDIA, B.V. 
First edition 1994

(C) 1994 Springer Science+Business Media Dordrecht

Originally published by Chapman \& Hall in 1994

Typeset by Thomson Press, India

ISBN 978-94-010-4312-0

Apart from any fair dealng for the purposes of research or private study, or criticism or review, as permitted under the UK Copynght Designs and Patents Act, 1988, this publication may not be reproduced, stored, or transmitted, in any form or by any means, without the prior permission in writing of the publishers, or in the case of reprographic reproduction only in accordance with the terms of the licences issued by the Copynght Licensing Agency in the UK, or in accordance with the terms of licences ssued by the approprate

Reproduction Rights Organization outside the UK Enquines concerning reproduction outside the terms stated here should be sent to the publishers at the London address prnted on this page.

The publisher makes no representation, express or implied, with regard to the accuracy of the information contained in this book and cannot accept any legal responsibility or liability for any errors or omissions that may be made

A catalogue record for this book is avalable from the Brtish Library

Library of Congress Cataloging-in-Publication data

Thin film diamonds / edited by A. Lettington and J.W. Steeds. - 1st ed.

p. $\mathrm{cm}$.

Includes index

ISBN 978-94-010-4312-0 ISBN 978-94-011-0725-9 (eBook)

DOI 10.1007/978-94-011-0725-9

1. Diamonds, Artificial 2 Diamond thin films. I. Lettıngton,

Alan H. II Steeds, J. W. III Royal Society (Great Britain)

TP873.5.D5T47 1994

$666.88-\mathrm{dc} 20$

93-33950

Prnted on permanent acid-free text paper, manufactured in accordance with the proposed ANSI/NISO Z39.48-1992 and ANSI/NISO Z39.48-1984 (Permanence of Paper). 


\section{Contents}

Contributors vii

Preface $\quad$ ix

1 Chemical vapour deposition of diamond 1

John C Angus, Alberto Argottia, Roy Gat, Zhidan Li, Mahendra Sunkara, Long Wang and Yaxin Wang

2 Thin film diamond growth mechanısms

James E Butler and Richard L Woodin

3 Microwave plasma CVD and related techniques for low pressure diamond synthesis

Peter K Bachmann

4 Local epitaxial growth of diamond on nickel from the vapour phase $Y$ Sato, $H$ Fujta, $T$ Ando, $T$ Tanaka and $M$ Kamo

5 The optical and electronic properties of semiconducting diamond Alan T Collins

6 The thermal conductivity of CVD diamond films $T R$ Anthony

7 Electron irradiation and heat treatment of polycrystallıne CVD diamond $C D$ Clark and $C B$ Dickerson

8 Strength, fracture and erosion properties of CVD diamond $J E$ Field, $E$ Nicholson, $C R$ Seward and $Z$ Feng

9 Deposition of diamond-like carbon $J$ Robertson

10 Applications of diamond-like carbon thin films Alan $H$ Lettington

11 Diamond as a wear-resistant coating $B$ Lux and $R$ Haubner

12 Thermal and optical applications of thin film diamond M Seal

Index 


\section{Contributors}

T. Ando National Institute for Research in Inorganıc Materıals, 1-1 Namıkı, Tsukuba, Ibarakı 305, Japan

John C. Angus Department of Chemical Engineering, Case Western Reserve University, Cleveland, Ohio 44106, USA

T. R. Anthony GE Research \& Development Center, P.O. Box 8, Schenectady, New York 12309, USA

Alberto Argoitia Department of Chemical Engineenng, Case Western Reserve University, Cleveland, Ohio 44106, USA

Peter K. Bachmann Philips Research Laboratories, Solid Films and Deposition Technologies, P.O. Box 1980, D-5100 Aachen, Germany

James E. Butler Code 6174, Naval Research Laboratory, Washington, DC 20375-5000, USA

C.D. Clark J J. Thomson Physical Laboratory, University of Reading, Whiteknights, Readıng RG6 2AF, UK

Alan T. Collins Wheatstone Physics Laboratory, Kıng's College London, Strand, London WC2R 2LS, UK

C. B. Dickerson J J Thomson Physical Laboratory, University of Readıng, Whiteknights, Reading RG6 2AF, UK

Z. Feng Computer Mechanıcs Laboratory, University of Calıfornia at Berkeley, USA

J. E. Field Cavendish Laboratory, Madingley Road, Cambridge CB3 0H3, UK

H. Fujita Central Research Laboratory, Onoda Cement Co. Ltd, 2-2-1 Ishıkawa, Sakura, Chiba 285, Japan

Roy Gat Department of Chemical Engineerıng, Case Western Reserve University, Cleveland, Ohio 44106, USA

R. Haubner Technical University Vienna, Institute for Chemical Technology of Inorganic Materials, Getreidemarkt 6/161, A-1060 Vienna, Austria 
M. Kamo Natıonal Instıtute for Research in Inorganıc Materıals, 1-1 Namıkı, Tsukuba, Ibarakı 305, Japan

Alan H. Lettington J J Thomson Physical Laboratory, University of Reading, Whiteknights, Reading RG6 2AF, UK

Zhidan Li Department of Chemical Engineerıng, Case Western Reserve University, Cleveland, Ohio 44106, USA

B. Lux Technical University Vienna, Institute for Chemical Technology of Inorganic Materials, Getreidemarkt 6/161, A-1060 Vienna, Austria

E. Nicholson Cavendish Laboratory, Madingley Road, Cambridge CB3 OHE, UK

J. Robertson National Power Labs, Leatherhead, Surrey KT22 7SE, UK

Y. Sato National Instıtute for Research in Inorganıc Matenals, 1-1 Namıkı, Tsukuba, Ibarakı 305, Japan

M. Seal Sigillum B.V., P.O. Box 7129, Amsterdam 1007 JC, The Netherlands

C. R. Seward Cavendısh Laboratory, Madıngley Road, Cambridge CB3 OHE, UK

Mahendra Sunkara Department of Chemical Engineering, Case Western Reserve University, Cleveland, Ohı 44106, USA

T. Tanaka Natıonal Instıtute for Research in Inorganıc Materıals, 1-1 Namıkı, Tsukuba, Ibarakı 305, Japan

Long Wang Department of Chemical Engineenng, Case Western Reserve University, Cleveland, Ohı 44106, USA

Yaxin Wang Department of Chemical Engineering, Case Western Reserve Unıversity, Cleveland, Ohı 44106, USA

Richard L. Woodin Norton Diamond Film, Northboro, Massachusetts 01532-1545, USA 


\section{Preface}

This volume contains a selection of invited review papers presented at a Royal Society Discussion meeting on Thin Film Diamond held in London on 15 and 16 July 1992

The topic of low pressure synthesis has attracted world wide interest and become increasingly active in recent years due to the possible use of diamond films in commercial applications

Until recently commercial diamond synthesis was almost entirely by the high pressure high temperature technique in which diamond is precipitated as an equilibrium phase from a carbon-containing liquid metal catalyst In this way crystals may be formed up to $10 \mathrm{~mm}$ or so in size The metastable low pressure techniques cannot compete in cost but can be used to fabricate large area wafers or predetermined shapes not possible by other means

Most of the low pressure techniques stem from the work of Eversole which was first reported in 1962 He exposed a hot diamond substrate alternately to a hydrocarbon gas, which deposited a mixture of diamond and graphite, and then to hydrogen, which preferentrally etched away the graphite In later developments these two stages have been combined to form a continuous process and differ only in the way the etchant is generated In this volume an historical overview of these low pressure growth techniques and a description of diamond and crystal morphology is given by John Angus and his co-authors in their paper on the chemical vapour deposition of diamond James Butler and Richard Woodin discuss the kinetics and gas phase chemistry involved in thin film growth and Peter Bachmann reviews the current deposition techniques $\mathrm{He}$ also summanzes the results of various deposition conditions and shows that diamond growth is possible only in a narrow range of gas compositions Y Sato and co-workers report on the local epitaxial growth of diamond on nickel substrates

Other papers discuss the electronic, optical, thermal and mechanical properties of thin diamond films The relationship between diamond and diamond-like carbon (DLC) is now better understood and this volume also contains papers on the electronic structure, deposition techniques and applications of DLC films

The final paper in this volume discusses the various thermal and optical infrared and X-ray applications of diamond thın films They have also been used in cuttıng and grinding and as the active element in semiconducting devices

The subject is advancing rapidly, with many patents being taken out each year It is nevertheless an opportune time to review the field since there is much fundamental and applied research that needs to be undertaken before this topic can realize its full potential It is hoped that this volume will provide a valuable overview of thin film diamond for years to come

A H LETTINGTON $\mathrm{J} W$ STEEDS 